\title{
BEING FIRST YEAR B.Ed. FOUNDATION PHASE STUDENT TEACHERS AT A UNIVERSITY: WRESTLING APPREHENSION IN AND THROUGH A CHOSEN CAREER
}

\author{
F. Ravhuhali* \\ Centre for Higher Education Teaching and Learning \\ e-mail: fhatuwani.ravhuhali@univen.ac.za
}

\section{Z. MacDonald}

Centre for International Teacher Education (CITE)

Cape Peninsula University of Technology

Cape Town, South Africa

e-mail: zahraamcdonald@hotmail.com

\section{T. S. Mashau*}

School of Education

e-mail: takalani.mashau@univen.ac.za

\section{P. N. Lavhelani*}

Centre for Higher Education Teaching and Learning e-mail: phellecy.lavhelani@univen.ca.za

\section{H. N. Mutshaeni*}

Centre for Higher Education Teaching and Learning

e-mail: nancy.mutshaeni@univen.ac.za

*University of Venda

Thohoyandou, South Africa

\section{ABSTRACT}

This article sought to understand the anxieties and challenges faced by Foundation Phase student teachers during their teacher training programmes and ask the following question: What are the student teachers' anxieties and challenges in regard to career path they have chosen in the near future? In this article, researchers argue that the vast number of students suffer from anxiety better known to themselves. The article argues that the diverse nature of anxieties experienced by student teachers might have varied adverse consequences and might lead to dropping out of the programme or simply leading a miserable career life. Qualitative exploratory design was utilised in which a purposive sampling procedure was adopted in selecting 383 respondents doing Foundation Phase Initial Teacher Education (ITE) programme from three universities. Data were 
thematically analysed. The most identified causes of student anxiety revolve around finances, selfesteem, career identities and choices conundrum. This article would not necessary provide all the answers but seeks to provide deeper understanding of the anxieties experienced by student teachers and provide credible empirical findings. The researchers recommend that this study be conducted in other universities across South Africa.

Keywords: career choice, academic anxiety, identity, foundation phase, pre-conceived images

\section{INTRODUCTION}

In the introduction, researchers present preliminary literature on factors that cause anxieties in order to build up to the overall discussion, most of which revolves around identity search and career choice and beliefs about teaching.

\section{ANXIETY AND STUDENT LEARNING}

Swift et al. (2014) indicate that many people are much more anxious these days than a few years ago. Described as a something that could happen in one's everyday life and a normal human emotion that anyone can experience at times (Goldberg 2014), financial issues such as money and debts are some of the most common sources or causes of anxiety amongst people. Strongman (1995) argues that the basic aspects of anxiety appear to be fear or fright and uncertainty of any threatening situation especially how to cope or deal with it. Anxiety can manifest itself either as characteristic anxiety which simply entails the stable characteristics of a human being or something that could be instigated by variety of conditions which can be temporary or permanent that a person finds himself or herself in. Such conditions may include such as examinations, misfortunes or simply penalty subjected to a person and many other conditions that look threatening to an individual (Nadeem et al. 2012). Goldberg (2014) states that anxiety is synonymous with a worrying feeling and being edgy about something with an uncertain outcome. In essence, people with anxiety are always concerned about the threat to their current goals and therefore, try to come up with various approaches or plans that can be applied to reduce such anxiety to achieve their own set of goals (Eysenck et al. 2007). Myers (2014) states that amongst different kinds of anxieties, generalised anxiety and phobias are some of those that are closely attached to feelings expressed by people from time to time. The generalised anxiety disorder is a feeling in which an individual is always worried or edgy even when there are no particular reasons to feel so while entails a feeling where a is a feeling whereby an individual is intensively and senselessly frighten by a specific condition or situation (Myers 2014).

Apart from generalised anxiety and the phobias, Goldberg (2014) highlights the societal anxiety disorder which entails any overpowering concerns in regard to daily circumstances, and 
social situations with most of the worry centred on the fear of being judged by others or behaving in a way that might cause embarrassment or lead to ridicule. With regard to students, Burns (2004) notes that anxiety amongst them tends to heighten during final examination periods as it is always related to performance expectations. This kind of anxiety is what Meetei (2012) refers to as "academic anxiety", and that it is related to the impending danger from the "academic institutions", including teachers and certain subjects such as Mathematics, English and many others.

Moreover, such an anxiety tends to impact negatively on student learning and well-being (Russell 2008). The negativity may include poor academic performance and under-achievement due to distractions and impaired verbal retention skills. Minahan and Rappaport (2013) note that a student may show poor engagement in class, poor self-efficacy, poor self-concept, and poor engagement. These may lead to drop out and lasting economic loses in relation to such an individual as well as the society (Dobson 2012; Lyneham 2009; Gamble 2009).

Strongman citing Fischer (1970) identifies five components embedded within the feeling of anxiety. The first component is "identity" which encompasses and manifest itself towards a way of living and if an individual's identity is threatened, a person may feel lost and anxious. Secondly, it is the "world" which constitutes various aspects of a person's personal and professional wellbeing. When this world looks insurmountable (passing a test, exam and attaining a degree), it may give rise to anxiety. Thirdly, is "motivation" which perpetuates a person's world and his or her identity. This would certainly mean that when anxiety is felt, an individual's motivation is affected. The fourth component is the "action" involved in achieving a milestone which might involve studying to become a teacher, and if threatened by issues within a person' world, anxiety is experienced. The fifth and the last component is the "ability" which is about an evaluation level of uncertain competence. This could explain why when student teachers are faced with complex and demanding tasks, they start to wonder and question their abilities in relation to what is expected or what will be expected from them as teachers (Strongman 1995).

\section{DEFAULT CAREER CHOICE AND A SEARCH FOR TEACHER IDENTITIES}

Council on Higher Education (CHE) (2015) notes that the vast number of students are most likely to choose their career directions during their first year of study or simply when they go to universities seeking admission to a particular programme. Students' sense of vocation identification with the chosen career together with psycho-social-emotional well-being and the provision of substantial necessities such as funding, are some of the dimensions, therefore impact their capabilities to do well at university (CHE 2015). 
Persistent failure by both their schools and the universities to provide proper vocational guidance to students, combined with limited knowledge of the vast range of career possibilities, is largely to blame (CHE 2015). Their inability to make informed vocational decision means that they have to follow study programmes that do not match their abilities or interests (CHE 2015). This makes it difficult for them to be successful at university or college and finding jobs (Crandell, Crandell and Vander Zanden 2012).

Furthermore, the majority of those young people who enter into initial teacher education programme do so with a very naïve understanding of the demands that await them or that accompany the teaching profession; they are only able to comprehend the complexities of the teaching profession through their continued years of study (De Beer 2013).

\section{PRE-CONCEIVED IDENTITIES AND IMAGES AMONG STUDENTS}

Sexton (2007) indicates that pre-service or the so-called entry-level teacher candidates' images and actions are influenced by their teachers while they were still students, "the type of teachers they would want to be and did not want to become". With those images, student teachers are able to build their own identities of the kind of teachers they certainly want to become. Beijaard (1995) highlights that identity is simply about who the person or someone is. It can be argued that identity has an element of uniqueness (how one identifies with himself or herself), and how others identify themselves. The "how" one identifies oneself is what determines the decision and provides justifications and reasons why student teachers choose to become teachers.

Tateo (2012) provides another perspective in relation to identity by equating identity as a way through which an individual is able to reflect and ardently assign one's own subjectivity in relation to his or her role in society. People become teachers for reasons that come from the mind as well as having some kind of passion to share some knowledge of a particular subject animated by a passion for some subjects and the zeal to help learners or children to acquire knowledge. As for student teachers, Palmer (1997) and Halvorsen (2014) they often have belief that can be able to make a difference in the lives of learners. These kind of student teachers' beliefs are equated to caring identity (Palmer 1997; Halvorsen 2014).

Such students harbour the feeling that they know what teaching is all about and "what the role of a teacher generally entails" (Chong, Ling and Chuan 2011). To them, own experiences of what they observed from their schools provide them with their own sets of what learners, schools and curricula is like (Britzman 1986). However, as times and years go by, people (in this case - teachers) tend to lose their heart of teaching. This is commonly observed on adolescents as they always have vague ideas about what they are able to do successfully, what they would enjoy doing, what requirements are attached to a given job, what the current job 
market is like and what it will probably be like in the future (Crandell et al. 2012), which gives rise to uncertainty and anxiety about career choice decisions.

The vast number of studies conducted worldwide and even South Africa, rarely looked at anxieties that are experienced by student teachers who are enrolled for B.Ed. and most specifically, the B.Ed. FP degree programmes. For an example, studies in regard to student teachers by Moodley, Adendorff and Pather (2015), Mapfumo, Chitsiko and Chireshe (2012) looked at stress and anxiety caused by teaching practice only and not necessarily on varieties of issues that cause anxiety amongst them. Given this and as highlighted earlier, this study sought to understand variety of anxieties that is experienced by first year B.Ed. FP student teachers enrolled for teacher education programme in South African universities.

\section{THE OBJECTIVE OF THE STUDY}

The article is aimed at understanding the anxieties and challenges of first year B.Ed. Foundation Phase student teachers during their teacher training programmes. The following research question underpins the aim of the article: What are the first year B.Ed. FP student teachers' anxieties and challenges in regard to their chosen future career path?

\section{Research design and methodology}

The qualitative phenomenological exploratory design was used, where interviews were conducted in order for participants to express their respective views and their overall perspectives of reality (Lodico, Spaulding and Voegtle 2006). A purposive sampling procedure was used to choose 383 first year B.Ed. Foundation Phase students were drawn from three universities. Two universities are in the Western Cape Province while the other one is in Gauteng. Two of the institutions are a universities of technology (UOTs) while the third one is a traditional university. Of the two UOTs, one has two campuses. One campus uses Afrikaans as medium of instruction while the other one uses English as a medium of instruction. The other UOT use English as a medium of instruction only. Although the B.Ed. Foundation Phase programmes were offered for four years, the modules offered in those programmes also differ in regard to content from one institution to the other. Collected data were thematically analysed.

\section{FINDINGS AND DISCUSSIONS}

The analysis of the responses provides a variety of anxieties they experience during their teacher training programme. Data are presented thematically as follows: uncertainties about career choice; not doing well in their studies; Identity role confusion and uncertainty; financial/tuition fees; workload; and teaching practice. The findings are presented with extracts from student 
teachers' responses. For some of the responses that are in Afrikaans, care was taken to ensure that they are presented as they are with English translations provided in brackets. Only few quotes were extracted from the wide range of responses in support of the findings.

\section{Uncertainty about career choice and the future plans}

One of the anxieties which is worrisome is that a number of student teachers expressed doubts about their career choice of being a teacher on whether they have made the right decision to become teachers. Others are not sure whether or not the career choice is the right one for them. Student teachers had this to say:

"Feeling uncertain about whether I chose the right degree or not."

"If it's the right career for me."

"I am not certain if I want to study teaching."

"I might have a change of mind maybe I would want to go in a different career path but yet I wouldn't want to 'drop out'.'

"I might not be able to fulfil my role as a teacher and being successful in a teaching profession."

"That I am not fit to become a teacher, realising that I belong somewhere else and not here."

"That I will not like it once I have completed my degree."

"That I will be a little boring each year teaching the same grade. Although my passion is children."

"The face of losing interest in this career."

"Dat ek later besef dat onderwys nie die regte beroep vir my was nie." (That I will later on feel that teaching is not a right career for me).

"That I won't enjoy teaching as much as I think I will once I have my degree."

"I am anxious about choosing between foundation phase and intermediate/senior phase, furthermore I fear being a poor teacher or failing my pupils."

"Maybe I have chosen the wrong career and keep struggling through the next few years."

"Feeling uncertain about whether I chose the right degree or not."

"That I am not fit to become a teacher, realising that I belong somewhere else and not here".

The uncertainties expressed here by participants show that they are anxious about their career choice and how they perceive their future career pathing. In most cases, this kind of uncertainty about career choices as Mlambo (2014) observed, is squarely blamed on the universities' faculties of education which are said to be unable to prepare student teachers in line with the authentic and real conditions of schools. Most importantly, this is cited as a reason why teachers are quitting from the profession very early in their careers (Mlambo 2014). Tateo (2012) adds to this discourse and indicates that the vast number of teacher training programmes are often found to be unable to support trainee teachers in order for them to cope well with the everyday 
teaching practice conditions that are sometimes negative. This results in most cases to tension between the typical representation of teachers' professional identity (TPI) and teachers' everyday experience. Drawing from Walters Doh-Nubia's doctorate paper, "the concepts of teacher resilience: a contribution towards teacher development". Betz and Voyten (1997) believe that decision-making self-efficacy is a major predictor of career uncertainty. Authors outlined that when one reaches a state of certainty in a career plan, remember to look back on period of uncertainty with gratitude as without it, there would be no success. It is clear that uncertainty plays an important role in an individuals' career decision process. In Taiwan, Tien's (2001) study, about two thirds of college students were undecided about their career futures due to lack of exploration, and commitment by students. This in the end, would certainly lead to anxiety as they later discover that they have chosen a wrong career option undecided about their career futures.

\section{Not doing well in their studies}

Participants indicated that they fear that they will either fail some of the modules or even fail to meet the requirements to graduate at the end of their ITE programme. This shows lack of confidence in the students' own abilities. Some of students' responses are as follows:

"Failing my course is my biggest fear."

"I fear that I will fail a subject."

"I might not be able to fulfil my role as a teacher and being successful in a teaching profession' I am scared of failure and therefore it gives me anxiety."

"Fear that I am going to fail, because everybody makes it sound so hard. I fear giving up and not succeeding. I fear failure, rejection and disappointment."

"I fear that I will drop out, because there is a lot of pressure on me."

"That I won't pass, that I won't be the best that I can be as a teacher. That there will always be someone better than me."

"My anxieties are that I will maybe fail in one of the subjects."

"Not passing well every year so that I can become the best teacher I possibly can. Teachers have difficult jobs."

"I am afraid to fail this year and the years ahead, and also to sit with a degree but not a job."

"To not be able to finish my work in the given time and to fail my course or to achieve below average."

"I'm scared that I would fail and won't be successful at the end of this year."

"The possibility of failing."

"Om nie al my vakke met goeie punte deur te kom nie." (Not to pass all my modules with good marks).

"That I can’t complete my studies." 
"That I fail due to all the subjects because I struggle in most subjects that we are doing in first year."

"That I may not pass all my subjects."

The results here show that participants are concerned and anxious about passing or doing well in their studies. Meetei (2012) states that in most cases, anxiety which is often experienced by students is what is referred to as "academic anxiety". It is an anxiety related to academic performance expectations (Burns 2004) and has much to do with how well students feel about their chances of doing well and pass at the end of academic year of their studies. These results are supported by Mudhovozi (2012) whose study found that students in their first year of study experienced anxiety in relation to failing at university as that might results in loss of sponsorship. This is shown by some of the first year students who indicated that their parents demand better results and that made them to be anxious about doing well in their studies.

\section{Identity confusion and lower self-esteem}

A number of respondents stated that they are not sure if they are good enough to become teachers and doubted their abilities to become good teachers. Some of them expressed that they doubt if they have chosen the right career path. These kinds of anxieties would indicate that perhaps some of the student teachers chose to become teachers by default or after observing what teaching and being teachers is all about. These students are starting to realise that they might not be able to do it. Some of the participants stated the following anxieties (such anxieties are expressed as) differently as follows:

"My voice projection as I'm a soft spoken how the learners will find me as a teacher and if they will be very fond of me."

"Will the children I teach, learn? Will I be an effective teacher I pray my passion for teaching does not go away?"

"That I may not be a good teacher who is able to understand the children and their needs."

"That I will fail in this chosen career path as I do not have the capability of what it takes to become a good teacher."

"I am not sure if I will be fit teacher who will be wanted (needed) in the society"

"Will I be a good teacher and will remember what I taught in years to come."

"I am scared that the learners might not want to listen to me due to the fact that I do not come forth as a future teacher."

"To be honest, my anxiety is that learners will take me for granted just because I am very short."

"That I will not be able to fulfil my role as a teacher." 
Strongman (1995) indicates that uncertainty cuts across as the core part of anxiety given that it is about being unsure of what the future holds or not knowing what course of action to take when one is threatened. Moreover, anxiety is equated to fundamental distress and a sense of helplessness which is normally experienced due to unavailability of plans or actions that are relevant to the task or situation. Webber (2018) notes that the undying quest to be perfectionist is one of the destructive aspects of low self-esteem. Participants in this study exhibit this kind of character which often displayed by people who live with a constant sense of failure due to a failure to recognize that they are unique and not incapable of doing something. This turn to manifest itself to constant anxiety about oneself.

\section{Finance/tuition fees}

Lack of finance or tuition fees was one of the anxieties expressed by students. Several students indicated that it is their biggest problem as it determines their progression to the next level of their studies and without it, they might drop out of their programme. Lack of finances could be due to the fact that they were unable to get a bursary, let alone a National Students Financial Aid Scheme (NSFAS) loan bursary. Students wondered if they would be able to complete their degree due to financial circumstances, and wondered if they would still be B.Ed. Foundation Phase students in the following year/s. Anxieties such as these interfere with students' studies. The following are some of the responses in relation to finance or tuition fees anxieties:

"That I am not funded in this current year I might face financial constrains to continue with my studies."

"My other biggest worry is finances."

"That maybe I won't receive a bursary for the following years."

"Where will I get funding next year? Will I even make it to next year I can't even pay for this year? Will I still be a B.Ed. Foundation Phase student next year?"

Insufficient funds and method of payment of their studies was identified, and not knowing how students are going to fund for their studies was identified by the CHE (2015) as a major challenge that tends to threaten students' chances of succeeding at the university. CHE (2015) further notes that the unfortunate part of all this is that students who are succeeding academically are not returning the following academic year because they are unable to access sufficient funding. Villette (2015) indicates that the majority of students who tend to drop pout or fail to return the following year, are those who are doing Foundation Phase (FP) programmes at various universities as they are either paying for their own studies or are using the National Financial Aid Scheme (NSFAS) funding. Few of them have external bursaries or other kinds 
of student loans, with an estimated 13972 being the lucky ones to have been granted the bursary in 2015 (Villette 2015). Even though the higher cost of teacher education has been highlighted in the Report of the Ministerial Committee on Teacher Education, noting specifically that a four-year full time B.Ed. programme is too costly for teacher education students, their families and communities to bear (DoE 2005), nothing has changed a decade or so later. This is seen in the study by Mudhovozi (2012) which found that the vast number of students highlighted financial constrains as their biggest challenge which made them very anxious about their studies. Furthermore, in her study, Pather (2015) found that ninety-four percent (94\%) of the student were in dire need of external funding such as the student loans, bursaries and scholarships to support their university life. According to Pather (2015), for the majority of students, the main priority was to secure financial aid before they can focus on academic activities.

\section{Workload}

A number of student teachers expressed their anxieties regarding the workload that they are faced with during their B.Ed. FP programmes. These workloads are related to tests, assignment tasks, individual and group presentations that they need to prepare for daily. The following are some of the responses:

"Increase workload of assignments and tests, as I believe the year ahead I will be a level 2 student everything will be more challenging."

"I'll let the work load over power me."

"I'm really worried about the workload."

"I fear the workload and lectures that are unreasonable."

"Will I be able to cope with the workload?"

"The workload and the pressure of being near perfect to successfully equip learners with what they need in terms of academic, emotional and social growth."

"The workload and whether or not my marks will be of satisfactory at the end of the year."

"The workload is too much, and I'm scared I'm not getting to it all."

"One of my anxieties is that I'm afraid that the work load for this year will get too much and then I won't return for my second year."

"I fear that the work would get too much and I won't be able to cope."

"That the amount of work we get will scare me and I wouldn't want to study further because of the heavy load of work we are packed with the whole time."

"Die werk in ons eerste jaar is geweldig baie en dit gaan net meer raak en wat ek die meeste vrees is dat dit soms voel daar is nie genoeg tyd om alles op datum klaar te maak nie." (The work during our first year is too much and it worries us a lot to an extent that it sometimes make me feel overwhelmed. 
"There is a lot more work than you think."

Being a student teacher in the first year of study can be a challenge, especially coming from high school where tasks were not that intense compared to universities. At the universities, there are several tasks which may include preparing and writing tests, planning and preparing for presentations, writing assignments - each one for a specific module pertaining to the teacher education programme. Supporting these findings, Gocken (2012) indicates that being a student teacher means one is always and constantly swamped with different tasks. The same findings on workload were highlighted in a study by Modipane (2011) which found that students complained of the heavy workloads as they have to grapple with a lot of assignments from different lecturers and too many theories to learn in a packed timetable.

Based on estimations, an average semester for a $1^{\text {st }}$ year student consists of 8 to 9 modules. Each of these modules has a set of assessment forms that need to be done before the end of each semester for marks to be tallied with the exam marks. If students are to do one project, one assignment, two tests and two presentations for eight modules, it would mean that at the end of the semester, they would have done 48 different tasks, excluding examinations.

\section{Teaching practice (TP)}

Teaching practice (TP) is one of the issues that some of the students are very anxious about. If indeed student teachers are anxious about teaching practice, this would indicate that perhaps they are not being well prepared for such sessions, and are simply being thrown into the deepend of the process. The following are some of the responses around teaching practice (TP) anxieties:

"One of my anxieties is not being able to pass my teaching practice."

"I do not enjoy critique lessons. I do not enjoy the pressure of having someone judge me."

"I am anxious for my next teaching practice because my first one went so badly and I had a terrible crit. I am also scared I might fail and repeat this year again because of my teaching practice."

"My anxieties are teaching practice and when we set evaluated it puts pressure on a person."

"My only current anxiety is teaching practice, session 2. The first session did not go well. However, for doing teaching as a career, I am very excited."

"The fact that on our second session of teaching practice we will be going to school to be given marks that will determine whether we will be going through second year next year. The fact that I might actual hates teaching and chooses another career."

"I am anxious for my next teaching practice because my first one went so badly and I had a terrible crit. I am also scared I might fail and repeat this year again because of my teaching practice."

"My anxieties are teaching practice and when we set evaluated it puts pressure on a person." 
"My only current anxiety is teaching practice, session 2. The first session did not go well. However, for doing teaching as a career, I am very excited"

Even though the 1995 National Teacher Education Audit Synthesis Report South Africa was released nearly two decades ago, some serious challenges which it highlighted with regard to the teaching practice are still being experienced today. For an example, TP was often applied as an adjunct to curriculum instead of being made an integral and central part of teacher training (Hofmeyr and Hall 1995). Such TP only focused more on the preparation of isolated lessons (Robinson 2005, in Hill, Thornhill and Alexander 2007).

Moreover, other challenges pertaining to teaching practice include: lack of proper guidance from the supervisors and educators from schools (Hamaidi et al. 2014); confusion in adapting theories and concepts they have learnt and adopted from their lecturers into real classroom situations (Liam 2012); not being provided with the manual of rules and regulations of teaching practices before going to the practising schools and failure by their supervisors to pinpoint serious shortcomings in student teachers' lesson planning (Gujjar et al. 2010); simultaneous roles of being teachers and students, their performance assessment by the supervisors, and management of relationships with and between supervisors (Schoeman and Mabunda 2012). It is worth noting that not all the programmes which the student teachers are enrolled for have yet been aligned with MRTEQ. They are however aligned to the Criteria for recognition and evaluation of qualifications for employment in education based on the Norms and Standard for Educators (NSE) (Department of Education (DoE) 2000). As for teaching practice the NSE (DoE 2000) highlighted the need for pre-service teachers to be assessed on their abilities to integrate theory and practice which is about the competencies to perform important teaching action or simply their practical competence (Department of Education (DoE) 2000). Moreover, the NSE policy stipulates that universities are allowed to develop and provide their learning programme in such a way that it should ultimately lead to the attainment of the learning outcomes or educator competence (DoE 2000). This would suggest that institutions had to design their ITE programmes as they see fit. Teacher educators were found to be using the seven roles of educators as stipulated in the NSE policy document as distinct generic competences and check lists thereby ensuring that all the listed competences (roles) were covered (DHET 2010, 8). Moreover, the seven roles were simply used as means to show policy compliance in terms of the form of the submission of programmes for evaluation rather than the substance of the actual curricula being offered (DHET 2010,8). The revised policy on the Minimum Requirements for Teacher Education Qualifications (MRTEQ) has since given clear guidelines in regard to the teaching practice as workplace-based and a critical component 
in the ITE programmes. MRTEQ stipulates that "teaching practice which is critical component of Work-integrated Learning (WIL) need to be structured, supervised, integrated into the learning programme, spread across the learning programme and it must be formally assessed" (DHET 2015, 13). Moreover, is expected for WIL to include aspects such as learning from practice which include observing and reflecting on lessons taught by others), as well as learning in practice which involves preparing, teaching and reflecting on lessons presented by student teachers (DHET 2015, 13). It is still not clear how these conditions of practical teaching are being incorporated in the ITE programmes given that it remains the "responsibility of the institution to formally arrange WIL opportunities for their students" (DHET 2015, 10).

\section{Implications and conclusions of the study}

Findings from this article do not warrant a conclusive generalisation of anxieties experienced by $1^{\text {st }}$ year ITE Foundation Phase student teachers in all teacher education providers in South Africa, given that the sample was drawn from only three universities. However, these findings may serve to provide a better understanding of the emotional turmoil that are not only faced by student teachers as they wrestle in their teacher training period in their quest to become teachers, but all other students enrolled in various degree programmes. Moreover, although this is a small sample, if these anxieties are felt by only this group, it could jeopardise and threaten the professional identity and development of pre-service or student teachers even before they graduate from their programme. The shortcoming of this article is that it came short in ascertaining (empirically) how anxiety is affecting the quality of teachers produced by teacher education institutions except what is being highlighted in the literature review such as underachievement and many others issues that may even lead to drop out from the programme. CHE (2015) indicates that even though students, when admitted to the universities, are provided with orientation programmes, these are not sufficient to help student to cope with life while studying. The unfortunate part for some of the students admitted in universities in South Africa is that there are very few first-year programmes to support them (CHE 2015).

It is worth noting that with all the anxieties expressed by Foundation Phase $1^{\text {st }}$ year cohorts, one would certainly wonder if students recruited to the ITE programmes are the best candidates, as envisioned in the Action Goal 14, given that some of the anxieties revolve around uncertainties in relation to their choices and identity. The underlying principle of the White Paper on Education and Training was the need to build a just and equitable system which provides good quality education and training to young and old learners throughout the country and to enable all individuals to value, have access to, and succeed in "lifelong education and training of good quality". However, as the cost of higher education continue to rise annually at 
the universities, thus creating serious access barriers for many students, one would wonder if these have ever been realised, given the anxieties that are experienced by student teachers during their training as educators. It's worth pointing out that with the announcement of free higher education the African National Congress (ANC) at its National Congress (ANC 2017), it still remains to be seen as how it will cover the students who are already in the system. This is so given that the Commission of inquiry into Higher Education and Training (2017) found that no-fee higher education is not feasible in South Africa while indications are that it will only be rolled out to first-year poor and working-class students in 2018 and then to be phased in over five years.

Moreover, with the establishment of the South African National Resource Centre for First Year Experience and Students in Transition (SANRC), it still remains to be seen if the centre will be able to effectively inform research in the field of student transitions from schools to universities (SANRC 2015). This is so given that the SANRC is aimed at improving student success in South Africa by disseminating research focusing specifically on the field of students' transition.

\section{RECOMMENDATIONS}

This article recommends that this study be conducted in other universities across South Africa. Given that many students have less than satisfactory schooling backgrounds, initial teacher education needs to go beyond the provision and attainment of formal qualifications and should, as recommended by the Report of the Ministerial Committee on Teacher Education (A National Framework for Teacher Education in South Africa), include consolidation of the basic tools for learning (Department of Education (DoE) 2005). Appropriate orientations to those who aspire to become teachers should be provided and should be aimed at engaging students in a deeper understanding of the real characteristics of the teaching profession, what it entails for one's career choice and broader implications. Such settings should challenge embedded assumptions about teaching and nurture a commitment to the ideals of the profession and training for specific tasks for teachers in particular institutional contexts. Most importantly, educational and management processes of education and training need to put the learners, in this case the aspirant teachers first. Moreover, teacher training should move beyond just training, and should endeavour to comprehend student teachers' knowledge and experience, taking into consideration, their needs, both materials and psychological, which have to be achieved through a cohesive approach to education and training. 


\section{REFERENCES}

African National Congress. 2017. "Remember Tambo: Towards unity, renewal and radical socioeconomic transformation." $54^{\text {th }}$ Congress of the ANC held on the $16^{\text {th }}$ to $20^{\text {th }}$ December 2017 in Johannesburg. http://www.anc.org.za/content/declaration-54th-national-conference-africannational-congress (Accessed 16 January 2018).

ANC see African National Congress.

Beijaard, D.1995. Teachers' prior experiences and actual perceptions of professional identity. Teachers and Teaching 1(2): 281-294.

Betz, N. E. and K. Voyten.1997. Efficacy and outcome expectations influence career exploration and decidedness. The Career Development Quarterly 46(2): 179-189.

Britzman, D. P. 1986. Cultural myths in the making of a teacher: Biography and social structure in teacher education. Harvard Educational Review 45(4): 442-456.

Burns, D. J. 2004. Anxiety at the time of the final exam: Relationships with expectations and performance. Journal of Education for Business 80(2): 119-124.

CHE see Council on Higher Education.

Commission of inquiry into Higher Education and Training. 2017. http://www.thepresidency.gov.za/ sites/default/files/Commission\%20of\%20Inquiry\%20into\%20Higher\%20Education\%20 Report.pdf (Accessed 16 January 2018).

Council on Higher Education. 2015. Content analysis of the baseline institutional submissions for phase 1 of the Quality Enhancement Project. Institutional Audits Directorate, May 2015.

Chong, S., L. E. Ling and G. K. Chuan. 2011. Developing student teachers' professional identities - an exploratory study. International Education Studies 4(1): 30-38.

Crandell, T. L., C. H. Crandell and J. W. Vander Zanden. 2012. Human development. $10^{\text {th }}$ Edition. New York: McGraw-Hill.

DBE see Department of Basic Education.

De Beer, J. 2013. Challenging students' perceptions of what it means to become a teacher. Annual Firstyear Excursion 9(1): 4. EDU.brief@UJ> (Accessed 10 January 2012).

Department of Education. 2000. Criteria for recognition and evaluation of qualifications for employment in education based on the Norms and Standards for Educators (NSE). Government Gazette Vol. 423, No 21565. Pretoria: Republic of South Africa, 22 September 2000.

Department of Education. 2005. A National Framework for Teacher Education in South Africa. The Report of the Ministerial Committee on Teacher Education. Republic of South Africa.

DHET see Department of Higher Education and Training.

Department of Higher Education and Training. 2010. Draft Policy on the Minimum Requirements for Teacher Education Qualifications selected from the Higher Education Qualifications Framework (HEQF). $\quad$ http://www.dhet.gov.za/Reports\%20Doc\%20Library/Draft\%20Policy\%20on\%20 minimum\%20requirements\%20for\%20Qualifications\%20in\%20Education.pdf (Accessed 25 May 2015).

Dobson, C. 2012. Effects of academic anxiety on the performance of students with and without learning disabilities and how students can cope with anxiety at school. A proposal submitted in partial fulfilment of the requirements for the degree of Master of Arts in Education at Northern Michigan University. $\quad$ https://www.nmu.edu/education/sites/DrupalEducation/files/UserFiles/Dobson Cassie_P.pdf. (Accessed 7 November 2015).

DoE see Department of Education.

Eysenck, M. W., N. Derakshan, R. Santos and M. G. Calvo. 2007. Anxiety and cognitive performance: Attentional Control Theory. Emotion 7(2): 336-353.

Fischer, W. F. 1970. Theories of anxiety. NY and London: Harper \& Row. 
Gamble, A. 2009. Anxiety and education: Impact, recognition and management strategies. Conference Proceedings: Mental Health and Wellbeing: Recognising Problems and Supporting School Aged Children. Hippocrate \& Socrate XIV 3 and 4 September 2009. http://www.cheri.com.au/ documents/MHWBProceedings_V2.pdf(Accessed 21 November 2015).

Gocken, L. 2012. Student teaching demands time commitment is a full workload. The collegian. http://www.kstatecollegian.com/2012/02/21/student-teaching-demands-time-commitment-is-afull-workload/ (Accessed 22 November 2015).

Goldberg, J. 2014. Anxiety disorders. Anxiety and panic disorders health center. http://www.webmd. com/anxiety-panic/guide/mental-health-anxiety-disorders (Accessed 20 November 2015).

Gujjar, A. A., B. Naoreen, S. Saifi and M. J. Bajwa. 2010. Teaching practice: Problems and issues in Pakistan. International Online Journal of Educational Sciences 2(2): 339-361.

Hamaidi, D., I. Al-shara, Y. Arouri and F. Abu Awwad. 2014. Student teachers' perspectives of practicum practices and challenges. European Scientific Journal 10(13): 191-213.

HDRC see Human Development Resource Council.

Hill, A., C. Thornhill and J. Alexander. 2007. Teaching reading: Student teachers and the schooling context. http://www.deta.up.ac.za/archive2007/presentations/word/Teaching\%20reading\%20 student $\% 20$ teachers $\% 20$ and $\% 20$ the $\% 20$ schooling\%20context $\% 20$ Uganda $\% 20 H i l 1 \% 20 \mathrm{~A}, \% 20$ Thornhill\%20C\%20,\%20Alexander\%20J.pdf (Accessed 29 July 2015).

Hofmeyr, J. and G. Hall. 1995. The National Teacher Education Audit: Synthesis Report. Johannesburg: Edupol, National Business Initiative.

Liam, E. 2012. Learning to teach: A descriptive study of student language Teachers in Taiwan. English Language Teaching 5(12): 152-162.

Lyneham, H. 2009. The impact of anxiety on student performance? https://www.aisnsw.edu.au/ Services/PL/SW/Documents/157496_Heidi_Lyneham_The_Impact_of_Anxiety_on_Student_Pe rformance.pdf (Accessed 7 November 2015).

Lodico, M., D. T. Spaulding and K. H. Voegtle. 2006. Methods in educational research: From theory to practice. Francisco: Jossey-Bass.

Mapfumo, J. S., N. Chitsiko and R. Chireshe. 2012. Teaching practice generated stressors and coping mechanisms among student teachers in Zimbabwe. South African Journal of Education 32(2): $155-156$.

Meetei, N. R. 2012. A critical study of impact of academic anxiety on academic achievement of class sixth students. http://www.scribd.com/doc/23767970/A-Ciritical-Study-of-Impact-of-AcademicAnxiety-on-Academic-Achievement-of-Class-Ixth-Students-Bareilly (Accessed 21 November 2015).

Minahan, J. and N. Rappaport. 2013. Anxiety in students: A hidden culprit in behaviour issues. kappanmagazine.org, 94(4): 34-39. http://www.nancyrappaport.com/files/34pdk_94_4.pdf (Accessed 26 November 2015).

Mlambo, S. 2014. Disillusioned teachers leaving profession. IOL News, 30 September 2014. http://www.iol.co.za/news/south-africa/kwazulu-natal/disillusioned-teachers-leaving-profession1.1758016\#.Vj6K1XzovZ4 (Accessed 7 November 2015).

Modipane, M. C. 2011. Initial experiences of first entering students at the University of Limpopo: Implications for coping with academic work/studies. South African Journal of Higher Education 25(8): 1592-1607.

Moodley, T., S. Adendorff and S. Pather. 2015. At-risk student teachers' attitudes and aspirations as learners and teachers of mathematics, South African Journal of Childhood Education 5(3): Art. \#218, 10 pages. http://dx.doi.org/10.4102/sajce.v5i3.218.

Mudhovozi, P. 2012. Social and academic adjustment of first-year university students. Journal of Social Science 33(2): 251-259.

Myers, D. G. 2014. Exploring psychology. $4^{\text {th }}$ Edition. New York: Worth Publishers. 
Nadeem, M., A. Ali, S. Maqbool and S. U. Zaidi. 2012. Impact of anxiety on the academic achievement of students having different mental abilities at university level in Bahawalpur (Southern Punjab) Pakistan. International Online Journal of Educational Sciences 4(3): 519-528.

Ncontsa, V. N. and A. Shumba. 2013. The nature causes and effects of school violence in South African high schools. South African Journal of Education 33(3): 1-15.

Palmer, P. J. 1997. The heart of a teacher: Identity and integrity in teaching. The essay from edited excerpts of the Introduction, Chapter I, and Chapter V. In The courage to teach: Exploring the inner landscape of a teacher's life, by Parker J. Palmer's. San Francisco: Jossey-Bass Publishers. https://biochem.wisc.edu/sites/default/files/labs/attie/publications/Heart_of_a_Teacher.pdf (Accessed 15 September 2015).

Pather, S. 2015. Financial stress distracts university students from academic success: The conversation. http://theconversation.com/financial-stress-distracts-university-students-from-academic-success49818 (Accessed 18 May 2017).

Robinson, M. 2005. Models for the initial professional education of teachers: 3 year B.Ed. +1 year Advanced Diploma: Induction OR 4 year B. Ed. Discussion document prepared for the Deans of Education forum of 20 October 2005.

Russell, G. 2008. Social anxiety: The elephant in your classroom? Education and Health 26(3): 50-53.

SANRC see South African partner of the National Resource Centre.

South African partner of the National Resource Centre. 2015. South African partner of the National Resource Centre for the First year Experience and Students in Transition housed at the University of South Carolina. Retrieved on November 15, 2015. From: http://sanrc.co.za/

Schoeman, S. and P. L. Mabunda. 2012. Teaching practice and the personal and socio-professional development of prospective teachers. South African Journal of Education 32(3): 240-254.

Strongman, K. T. 1995. Theories of anxiety. New Zealand Journal of Psychology 24: (2):4-10.

Sexton, S. S. 2007. Power of practitioners: How prior teachers informed the teacher role identity of thirty-five entry-level pre-service teacher candidates. Educate 7(2): 46-57.

Swift, P., E. Cyhlarova, I. Goldie and C. O'Sullivan, P. Bristow, J. Carson, H. Biggs and J. Edwards. 2014. Living with anxiety: Understanding the role and impact of anxiety in our lives. Mental Health Awareness Week 2014. Mental Health Foundation. http://www.mentalhealth.org.uk/ content/assets/PDF/publications/living-with-anxiety-report.pdf?view=Standard (Accessed 21 November 2015).

Tateo, L. 2012. What do you mean by "teacher"? Psychological research on teacher professional identity. Psicologia \& Sociedade 24(2): 344-353.

Tien, H. S.2001. Career decision-making difficulties perceived by college students in Taiwan. Bulletin of Educational Psychology 33(1): 87-89.

Villette, F. 2015. Student teachers funding shock. Cape Times, 18 May. http://www.iol.co.za/ news/south-africa/western-cape/student-teachers-funding-shock-1.1859687\#.Ve7Cv9KeDGd (Accessed 28 August 2015).

Webber, C. 2018. How to overcome low self-esteem. The Netdoctor. https://www.netdoctor. co.uk/healthy-living/wellbeing/a25866/how-to-overcome-low-self-esteem/ (Accessed 6 July 2018). 